\title{
Enzymatic Activities, Characteristics of Wood-Decay and Wood Substrate Specificity within Genera of Some Wood-Rotting Basidiomycetes from Cameroon and Tropical Africa
}

Fabrice Tsigaing Tsigain, Blondo-Pascal Metsebing, Dominique Claude Mossebo, Leif Randulff Ryvarden, Romuald Oba, Choupo Guifo, Nkodo Ekemé, Frank Trésor Mvomo Andela, Annette Lauriane Megne, Nelly Amanda Simé, Sylvie Eudoxie Ngo Mbock, and Ulrich Landry Fokoua

\section{ABSTRACT}

A total of 72 species of wood-rotting Basidiomycetes belonging to 40 genera, 13 families and 5 orders, were investigated in this study of which 46 for the first time as far as type of wood-rot is concerned. 61 of the 72 cause white rot $(W)$ representing $84.72 \%$ of the total and 11 cause brown rot (B) or just $15.27 \%$, confirming the predominance already known of white rot $(W)$ on brown rot (B) as shown in other studies. Results recorded show that even though most species belonging to same genera display the same type of rot (W or B), species of some few other genera were found to rather display different types of rot (W and $B)$ in species within the same genera. Other results show that when determining the type of wood-rot caused by some species of fungi, in case of negative (-) test using tincture of guaiac which is known as the key test to determine the type of rot, syringaldazine must also be used as a differential test before concluding whether the species is a white (W) or brown rot (B) fungus. The level of activity of tyrosinase and peroxidase shows important variations between species of some genera, whereby some species of a given genus show varying potential level $(+,++$, $+++,++++)$ of activities of these two enzymes, whereas other species of the same genus show no sign (-) of activity of the same enzymes. Therefore, our results led to the conclusion that the presence $(+,++,+++,++++)$ or absence $(-)$ of activity of peroxidase and tyrosinase can from now onwards also be used as an enzyme linked taxonomic criteria to distinguish between species of some genera. About detection of laccases activity, if a negative (-) result occurs during detection test in a wood-rotting fungus using syringaldazine, $\alpha$-naphtol must also be used as a differential test before concluding on whether the species produces laccases or not. Based on the overall results recorded in the detection of enzymes activities, it appears necessary to use, where indicated, several substrates with different chemical sensitivities to detect the existence of an enzyme and its potential activity level in a fungal species. Additionally, preliminary lists of wood-decay fungi with potentially strong $(+++,++++)$ capacity to produce different types of polyphenol oxidases potentially usable in paper making industries, wastewater treatment and soil remediation, are provided. With regard to the study of substrate specificity which aimed at finding out the existence or not of a specificity between polyporales and tree wood species on which they grow, the first results recorded on a limited number of trees investigated led to the preliminary conclusion that, although some few tree species may serve as hosts for only a single species of polyporales, there is rather a greater tendency of finding several species growing on different species of wood as well as the same species of wood hosting several species of polyporales. These field observations led to the remark that a much larger inventory including a greater number of tree species in various tropical ecosystems is necessary in order to come out with a final conclusion.

Keywords: Differential tests of detection, sensitiveness of different detection substrates, polyphenol oxidases activities and taxonomic implications, woodrotting basidiomycetes, wood substrate specificity.
Published Online: January 3, 2022

ISSN: $2684-5199$

DOI : $10.24018 /$ ejbio.2022.3.1.315

F. Tsigaing Tsigain

Mycological Laboratory, University of

Yaoundé 1, Cameroon.

(e-mail: ftsigaing@yahoo.fr)

B. P. Metsebing

Mycological Laboratory, University of

Yaoundé 1, Cameroon.

(e-mail: bmetsebing@yahoo.com)

D. C. Mossebo *

Mycological Laboratory, University of Yaoundé 1, Cameroon.

(e-mail: dmossebo@yahoo.fr)

L. R. Ryvarden

Department of Botany, University of Oslo, Norway.

(e-mail: leifryvarden@ibv.uio.no)

R. Oba

Mycological Laboratory, University of Yaoundé 1, Cameroon.

(e-mail: romuald_oba@yahoo.fr)

C. Guifo

Mycological Laboratory, University of Yaoundé 1, Cameroon.

(e-mail: guifochoupo1990@gmail.com) N. Ekemé

Mycological Laboratory, University of Yaoundé 1, Cameroon.

(e-mail: k3nkodo@gmail.com)

F. T. Mvomo Andela

Mycological Laboratory, University of Yaoundé 1, Cameroon.

(e-mail:

tresianomahombe72@gmail.com)

A. L. Megne

Mycological Laboratory, University of Yaoundé 1, Cameroon.

(e-mail:

megneannettelauriane@gmail.com)

N. A. Simé

Mycological Laboratory, University of Yaoundé 1, Cameroon.

(e-mail: nellyasimelda17@gmail.com) S. E. Ngo Mbock

Mycological Laboratory, University of Yaoundé 1, Cameroon.

(e-mail: sylvieeudoxie@gmail.com) U. L. Fokoua

Mycological Laboratory, University of Yaoundé 1, Cameroon.

(e-mail: fulrichlandry@gmail.com)

*Corresponding Author 


\section{INTRODUCTION}

Wood-rotting Basidiomycetes are found worldwide and constitute an important part of the fungal flora of various ecosystems including rain forests of tropical Africa. Many of the tropical polypores are pantropical and this flora may to a certain extent also be found in other parts of Africa and even in tropical Asia and America (Ryvarden \& Johansen, 1980). Polypores collected on the field among which some recently described new species constitute the large majority of species investigated in this study and numerous potential new species are still to be collected and described in the rain forests and various other ecosystems of Africa south of Sahara. Wood fungi in general are highly important in forestry ecosystems. Besides their natural role in wood degradation through two major types of wood rot including white and brown rot, thereby contributing to the clearing of forests, some fungal oxidative enzymes they produce are used in various industrial and sanitation processes including biopulping in paper making industries, waste water treatment and soil remediation (Mossebo et al. 2007), food processing and browning reactions (Mayer, 2006) and some other biotechnological processes such as the production and purification of enzymes for other uses (Mossebo et al. 2007; Stalpers, 1978).

Since the works of (Bavendamm, 1928) on the determination of extracellular phenoloxidases (oxidative enzymes) in some wood-rotting fungi, enzymatic activities in various groups of fungi have been widely studied by several authors using species collected in various parts of the world. However, in spite of its rich fungal biodiversity in various forestry ecosystems as mentioned above, very little research has been undertaken into fungal enzymatic activities in species from tropical Africa. Among the few noteworthy papers are those of Mossebo et al., 2007; Boidin \& Lanquetin, 1983; Boidin \& Lanquetin, 1995; Mossebo, 2002; Njounkou \& Mossebo, 2012 and Mswaka \& Magan, 1998. Focus in this geographical area has mainly been on taxonomic and systematic issues, given the numerous still undescribed species in the tropics.

Elsewhere, never a study has been published in tropical Africa on the issue of wood fungi in general with regard to the specificity of their hosting wood, or in short, which species of polypores or mushrooms in general grow on which species of wood? In fact, polypores being mostly saprophytic with only very few parasitic species, they are most often collected on dead wood and very few on living wood. Therefore, a clear answer to the above-mentioned question could eventually enable collectors or researchers to determine which species of living trees later on became dead wood to host these polypores, or on the contrary, the answer to the above question could also enable to forecast which species of polypores or mushrooms will later grow on dead wood (tree trunks and stumps) derived from a known living tree.

About polyphenol oxidases, various methods are used to determine the existence and assess the level of extracellular oxidases activity in fungi. These techniques include among others, agar-plate assays (Bavendamm, 1928; Boidin \& Lanquetin, 1983; Boidin \& Lanquetin, 1995; Boidin, 1951; Nakasone, 1990) and spot tests on mycelial cultures and sporocarps (Mossebo et al. 2007; Stalpers, 1978; Mossebo, 2002; Njounkou \& Mossebo, 2012; Harkin \& Obst, 1973;
Harkin et al.,1974; Käärik, 1965; Marr, 1979; Marr et al., 1986; Nobles, 1958). Spot tests on mycelial cultures are particularly useful for polypores or other species with basidiocarps showing colors different from white, as it is the case in most of the species (Table I) investigated in our study. In fact, considering the difficulties of directly performing spot tests in vivo on carpophores on which the substrate shift of color - which is the main assessment criteria in spot tests - can hardly be observed, since it is masked by the sporocarps' natural colors, these spot tests performed on mycelium (mostly white) in culture are much easier to interpret, and therefore constitute one of the best and most reliable ways to assess enzymatic activities in these species.

To summarize the above-mentioned issues, this work aimed at:

- extending the study carried out several years ago by (Mossebo et al. 2007) on the knowledge of wood-rotting Basidiomycetes from Cameroon and their enzymatic activities. Just 22 species from Cameroon were investigated in the study of 2007 ;

- comparing the type of wood-decay within species of the same genera;

- comparing the nature and potential level of enzymatic activities in species belonging to the same genera in order to find out whether they comply with the taxonomic delimitation of these species;

- comparing the level of sensitiveness of some reagents meant to determine the type of wood-decay;

- comparing the level of sensitiveness of some reagents meant to detect the presence of the same enzyme and its potential level of activity;

- attempting a taxonomic grouping of species according to their enzymatic activities;

- providing separate lists of wood-rotting Basidiomycetes showing high potential level $(+++,++++)$ of enzymes production (unspecific polyphenol oxidases, laccases, tyrosinase, peroxidase) that could eventually be used for various industrial processes mentioned above;

- finding out the existence or not of a specificity between the wood-rotting Basidiomycetes and the hosting wood.

In order to reach the above mentioned goals, 72 species of wood-rotting Basidiomycetes from Cameroon and tropical Africa were investigated, of which 46 for the first time as far as the determination of type of wood-rot is concerned.

\section{MATERIALS AND METHODS}

\section{A. Enzymatic Activities and Characteristics of Wood- Decay}

Seventy two (72) species (Table I) of wood-rotting Basidiomycetes belonging to 40 genera and 13 families were investigated in this study of which 46 for the first time for their enzymatic activities and related decay characteristics using spot tests reagents in mycelial cultures. These species also growing elsewhere in tropical Africa were all collected in Cameroon and jointly identified by us and Ryvarden (pers. comm.) using among other documents Ryvarden \& Johansen, 1980; Ryvarden \& Melo, 2014 and for some recently described new species also tested in this study, some additional documents including Ambit \& Mossebo, 2015; Metsebing et al., 2019; Mossebo \& Ryvarden, 1997; 
Mossebo \& Ryvarden, 2003; Oba et al., 2020; Pegler, 1977; Pegler, 1983 and Tsigaing et al., 2019 were also used. One of our first findings during identification based mostly on Ryvarden \& Johansen, 1980 is that most of the 72 species (Table I) equally grow in several other countries of tropical Africa.

Mycelium was grown for 7 to 14 days on Malt Extract Agar (15 g Agar Agar (Merck), 20 g Malt Extract (Merck), 1L distilled water) in $9 \mathrm{~cm}$ petri dishes either from spores dilution or explants from basidiocarps context. The identification of oxidizing enzymes and their potential level of activity was carried out with common substrates used for drop tests at the edge of actively growing mycelium according to Käärik, 1965 and Stalpers, 1978; guaiacol being applied differently according to Tichy et al., 1962 (cit. by Kreisel \& Schauer, 1987). Tincture of guaiac and guaiacol were used as non-specific polyphenol oxidase reagents, the first being prepared by adding $0.5 \mathrm{~g}$ of gum guaiac powder (Merck) to $30 \mathrm{ml}$ of $95 \%$ ethanol and the second as $1 \%$ solution of guaiacol (Merck) in distilled water. The response to tincture of guaiac was assessed according to Nobles, (1958) and according to whom the rapid appearance of blue color (Fig. 2 (1)) indicated a positive result that also determined white rot (Fig. 3) fungi, while no change or tardy appearance of pale blue color indicated a negative result and thereby brown rot (Fig. 4) fungi. Syringaldazine was also used in some cases as substitute to guaiac for the identification of white rot according to Harkin \& Obst, 1973; Harkin et al., 1974 and Gilbertson, 1981. Laccases substrates were $\alpha$-naphtol (Fluka) and syringaldazine (Sigma-Aldrich) used as originally indicated by Käärik et al., 1965 and Stalpers, 1978 for the first and for the second by Harkin \& Obst, 1973 and Harkin et al., 1974. P-cresol (Merck) [Fig. 2(2)] and $\mathrm{H}_{2} \mathrm{O}_{2} /$ Pyrogallol (Merck) [Fig. 2(5)] were used to measure the oxidizing activity of tyrosinase and peroxidase respectively.

Control tests were undertaken either with distilled water or $95 \%$ ethanol according to which of the two was used as solvent in the substrate. Activities of all the above-mentioned substrates on the 72 fungal species tested were compared with particular attention in genera for which more than one species were tested for enzymatic activities.

Results of spot tests (Fig. 2) with most substrates ( $\alpha$ Naphtol, p-cresol, guaiacol, $\mathrm{H}_{2} \mathrm{O}_{2}$ /pyrogallol) were regularly recorded at $3 \mathrm{H}, 24 \mathrm{H}$ and $72 \mathrm{H}$, but guaiac test results were assessed according to Nobles, 1958 as explained above. The commonly used code + and - indicated positive and negative results respectively and the assessment scale,,++++++ , ++++ derived among others from Boidin \& Lanquetin, 1983; Boidin \& Lanquetin, 1995; Boidin, 1951; Nakasone, 1990; Nobles, 1958 and Charbonnel, 1995 indicated the shift in color intensity of the reagent and its rating $(+,++,+++$, $++++)$. Additionally, a tentative taxonomic value of the enzymatic activities recorded is proposed by grouping species according to their response to various substrates tested.

\section{B. Wood Substrate Specificity to Wood-Rooting Fungi}

Specially for this study, all specimens of polyporales were collected in a registered forestry parceling out unit (UFA $\mathrm{N}^{\circ}$ 10-010) (Fig. 5) situated in Libongo village in the eastern region of Cameroon, division of Boumba and Ngoko, subdivision of Salapoumbé, between the latitudes $2^{\circ} 30^{\prime} 08^{\prime \prime}$ to $2^{\circ} 47^{\prime} 14^{\prime \prime}$ North and longitudes $15^{\circ} 36^{\prime} 00^{\prime \prime}$ to $16^{\circ} 01^{\prime} 10^{\prime \prime}$ East. This sampling area was chosen for its immensely rich biodiversity including a great variety of species of the tropical rain forest. Polyporales were collected in August and September 2019 on dead tree stumps and trunks on which the forestry company ("SEFAC") operating in the UFA attributed to each of these items, a code number just after cutting down the living tree for its wood, followed by taxonomic identification by the company. These code numbers and the corresponding tree names as well as the GPS recorded geographical references of the felled trees in the forest were conserved in the archives of the operating forestry company and were later on borrowed to us on request to find back the names of the tree species corresponding to the dead trunks and stumps on which the polypore species were collected during our field inventory. As explained earlier, the final aim was to establish or not a correlation between the polypores collected and the species of the hosting wood that could help forecast the species of mushrooms expected on dead wood originating from a known living tree.

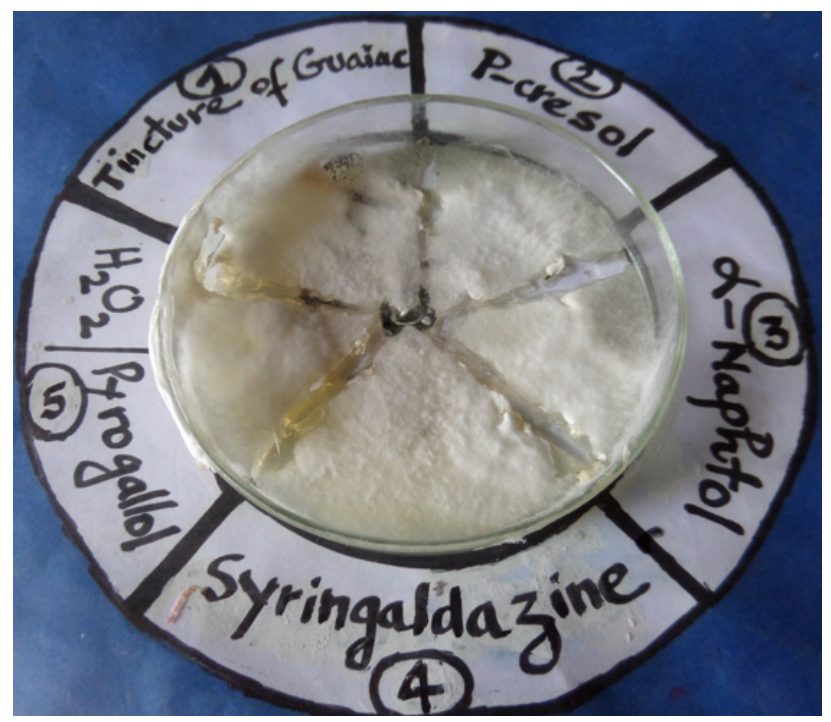

Fig. 1. Mycelial culture subdivided into portions in a petri-dish and ready for spot-tests with various substrates $(1,2,3,4,5)$.

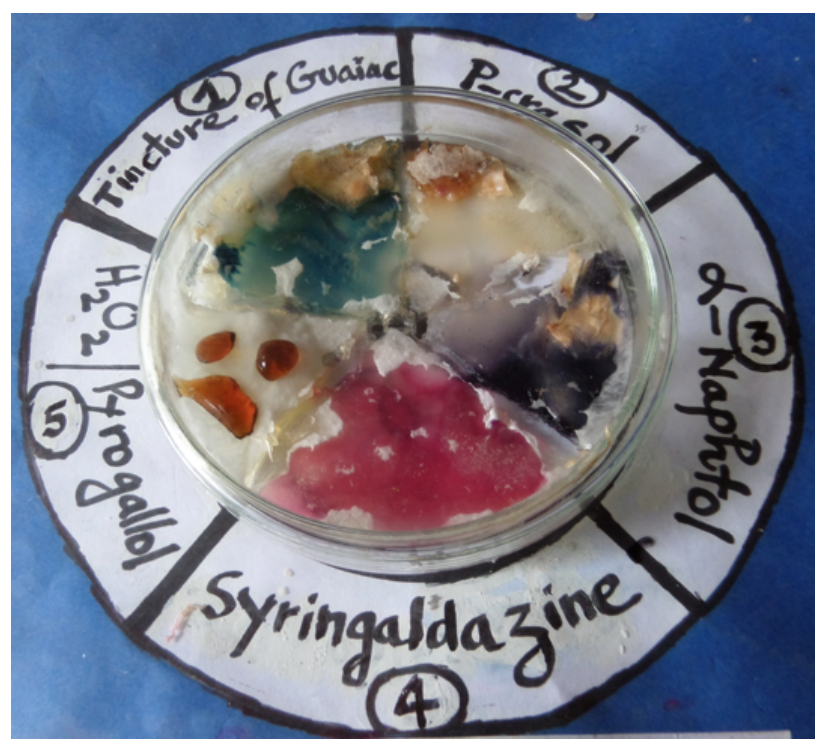

Fig. 2. Colored reaction of guaiac (1) showing type of wood-decay. Color intensity $(1,2,3,4,5)$ shows different levels of potential enzymatic activities of the tested wood-rotting fungi. 


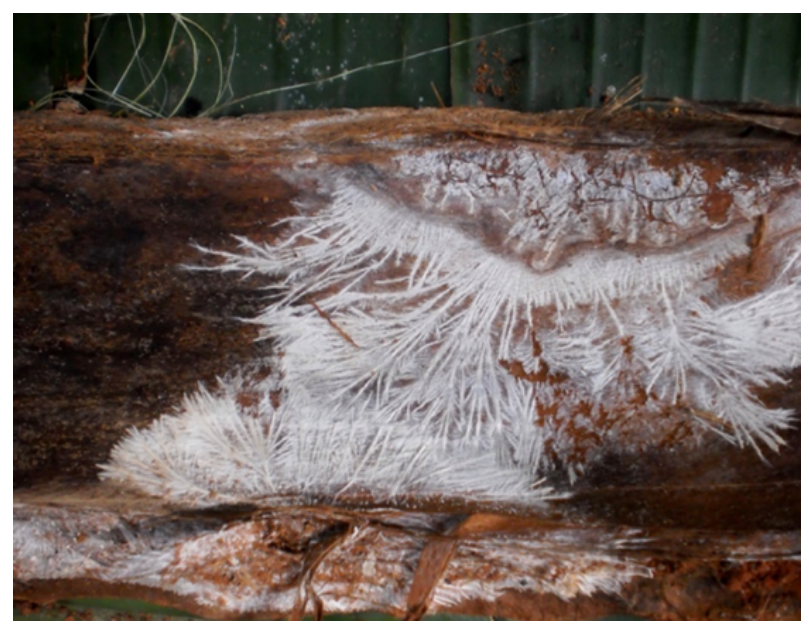

Fig. 3. White rot (W) on wood caused by a white-rot fungus.

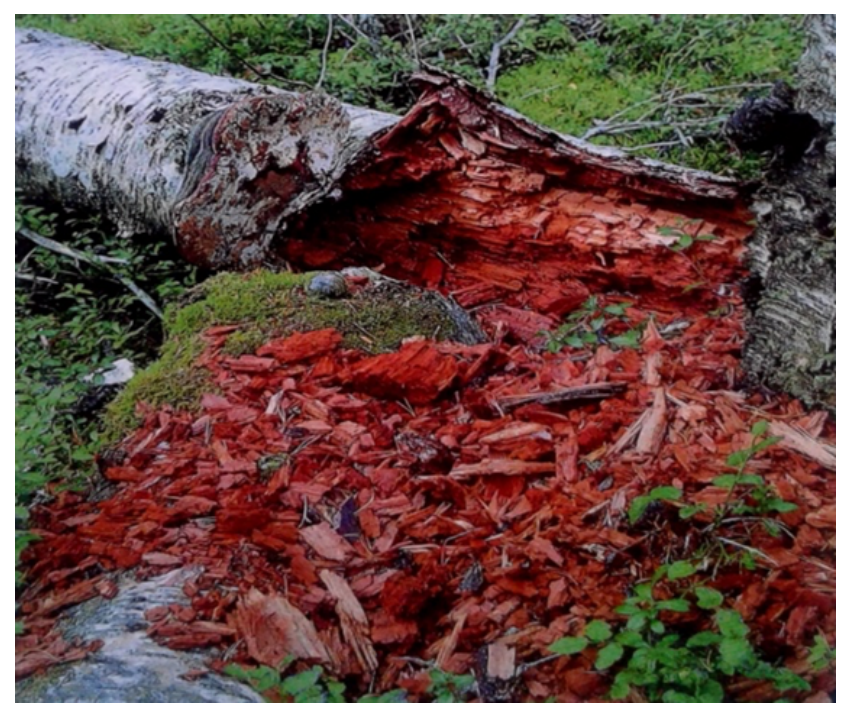

Fig. 4. Brown-rot (B) on a tree trunk of an angiosperm caused by a brownrot fungus. Photo Leif Ryvarden.

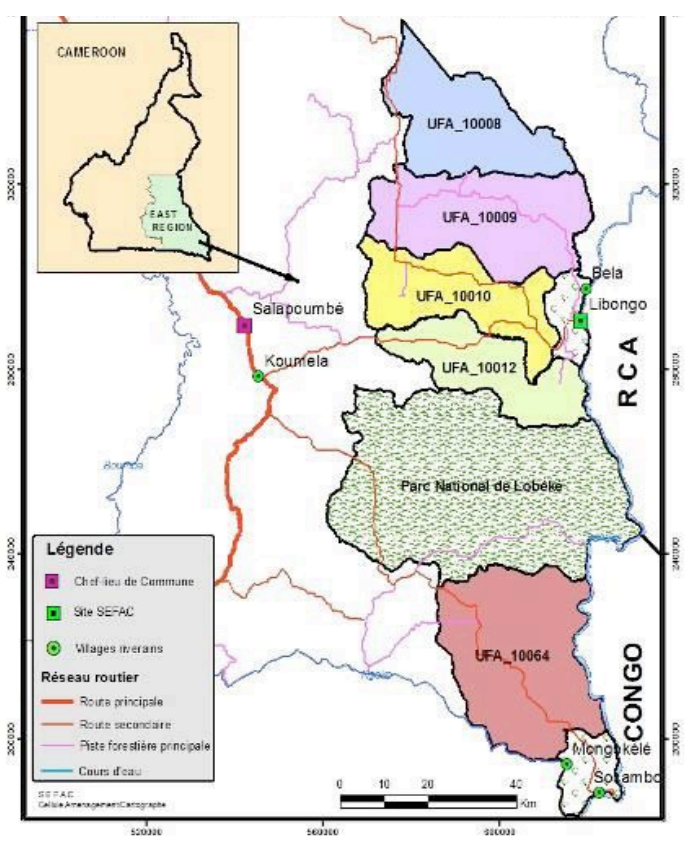

Fig. 5. Area of collection (UFA 10-010: highlighted in yellow) of the SEFAC forestry company in the Eastern Region of Cameroon (Ref. Parag. II-B and III-E: Wood Substrate Specificity to Wood-Rooting Fungi).

Cameroon is on the top left of the map and the East Region of Cameroon is zoomed on the right.

\section{RESULtS}

\section{A. Enzymatic Activities and Type of Wood-Rot}

The following remarks could be drawn from results recorded in Table I according to the below mentioned topics:

1) Predominance of white on brown rot in wood rotting Basidiomycetes

In a total of 72 species (Table I) investigated, the guaiac and syringaldazine tests revealed that 61 cause white rot $(\mathrm{W})$ representing $84.72 \%$ of the total and 11 cause brown rot (B) or just $15.27 \%$.

2) Wood-decay characteristics determined by the comparative detection of enzymatic activities using various substrates

Although guaiac test as developed by Nobles, (1958) is universally recognized as the best test to determine the type of wood-decay, some tests results carried out with this reagent were equivocal with regard to time and color of reaction as defined by Nobles, (1958), so much so that a differential test was necessary with syringaldazine which according to Harkin \& Obst, 1973 and Harkin et al., 1974 also determine the type of wood rot. So, the following species including Flavodon flavus, Lentinus cladopus, Lentinus villosus, Serpula eurocephalus and Trametes modesta, originally classified as brown rotters because testing negative $(-)$ with guaiac or showing a very weak $[(+)]$ activity or late reacting (change of color) with this substrate (guaiac), were later reclassified and rather considered as causing white rot due to a clear and unequivocal positive test revealed by syringaldazine as shown in Table II:

TABLE II: DiFFERENTIAL TESTS CARRIED OUT WITH GUAIAC AND SYRINGALDAZINE TO DETERMINE THE TYPE OF ROT CAUSED BY SOME WOOD ROTTING BASIDIOMYCETES

\begin{tabular}{|c|c|c|c|c|}
\hline \multirow[t]{2}{*}{$\mathrm{N}^{\circ}$} & \multirow[t]{2}{*}{$\begin{array}{c}\text { Species of } \\
\text { polyporales }\end{array}$} & \multicolumn{2}{|c|}{$\begin{array}{c}\text { Differential tests results } \\
\text { carried out with guaiac and } \\
\text { syringaldazine }\end{array}$} & \multirow{2}{*}{$\begin{array}{l}\text { Conclusion on } \\
\text { the type of } \\
\text { wood-rot }\end{array}$} \\
\hline & & Guaiac & Syringaldazine & \\
\hline 1. & Flavodon flavus & 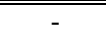 & + & $\overline{\mathrm{W}}$ \\
\hline 2. & Lentinus cladopus & $(+)$ & $+(+)$ & W \\
\hline 3. & Lentinus villosus & $(+)$ & ++ & W \\
\hline 4. & $\begin{array}{c}\text { Serpula } \\
\text { eurocephalus }\end{array}$ & - & ++++ & W \\
\hline 5. & Trametes modesta & - & ++++ & W \\
\hline
\end{tabular}

Remark - Results recorded in Table II show that when determining the type of wood-rot caused by some species of fungi, in case of negative (-) test using tincture of guaiac which is worldwide known as the best test to determine the type of wood-rot, syringaldazine must also be used as a differential test before concluding whether the species tested is a white (W) or brown rot (B) fungi.

\section{3) Characteristics of wood decay within species of the same genera}

With regard to the characteristics of wood decay within genera of wood rotting Basidiomycetes, a comparison of some tests results (Table III) between species belonging to the same genera show two major findings whereby in the first, all species tested in some genera display a perfectly uniform type of rot, either white such as for Lentinus, Microporus, Phellinus and Pleurotus to name a few, or brown as for both species of Gymnopilus tested in this study. In the second finding concerning rather few genera such as Coriolopsis, Perenniporia, Phellinus, Rigidoporus, and Trametes, the type of rot is shared between white and brown for species tested in the same genera as shown in Table III. 
TABLE I : MAXIMUM ENZYMATIC ACTIVITY LEVEL DeTECTED BY VARIOUS SUBSTRATES IN MYCELIAL CULTURES AND TYPe OF WOOD-DECA

\begin{tabular}{|c|c|c|c|c|c|c|c|c|c|}
\hline \multirow{2}{*}{ Higher Basidiomycetes tested } & \multicolumn{3}{|c|}{ Phenoloxydases and type of rot } & \multirow{2}{*}{$\begin{array}{c}\downarrow \quad \text { Laccases } \\
\alpha \text { - Naphtol }\end{array}$} & \multirow{2}{*}{$\begin{array}{c}\downarrow \\
\begin{array}{c}\text { Syringal- } \\
\text { dazine }\end{array} \\
\end{array}$} & \multirow{2}{*}{$\begin{array}{c}\begin{array}{c}\text { Tyrosi- } \\
\text { nases }\end{array} \\
\text { P-cresol }\end{array}$} & \multirow{2}{*}{$\begin{array}{c}\text { Peroxy-dases } \\
\mathrm{H}_{2} \mathrm{O}_{2} / \\
\text { Pyrogallol } \\
\end{array}$} & \multirow{2}{*}{$\begin{array}{l}\text { Enzymes } \\
\text { produced in } \\
\text { each species }\end{array}$} & \multirow{2}{*}{$\begin{array}{l}\text { Source of the enzymatic } \\
\text { activities recorded in this Table }\end{array}$} \\
\hline & Guaïc & $\begin{array}{l}\text { Type } \\
\text { of wood-rot }\end{array}$ & Guaïcol & & & & & & \\
\hline \multirow{2}{*}{\multicolumn{10}{|c|}{$\begin{array}{c}\text { POLYPORALES } \\
\text { Polyporaceae }\end{array}$}} \\
\hline & & & & & & & & & \\
\hline Abundisporus roseoalbus (Jungh.) Ryv. & +++ & $\mathrm{W}$ & 1 & 1 & 1 & l & 1 & & This study \\
\hline Amylosporus campbelli (Berk) Ryv. & $++(+)$ & $\mathrm{W}$ & i & 1 & 1 & i & / & & This study \\
\hline Cerrena meyenii (K1.) Hansen & +++ & W & 1 & 1 & 1 & 1 & 1 & & This study \\
\hline Climacodon pulcherimus (Berk. \& Curtis) Nikloajeva & - & B & - & $(+)$ & - & - & ++ & $\mathrm{L}, \mathrm{P}$ & This study \\
\hline Coriolopsis byrsina $(\mathrm{Fr}$.) Ryv. & +++ & $\mathrm{W}$ & / & 1 & I & 1 & 1 & & Mossebo et al. (2007) \\
\hline Coriolopsis floccosa (Jungh.) Ryv. & +++ & W & 1 & 1 & 1 & 1 & 1 & & Mossebo et al. (2007) \\
\hline Coriolopsis polyzona (Pers.) Ryv. & ++++ & $\mathrm{W}$ & ++++ & ++++ & +++ & - & ++ & $\mathrm{L}, \mathrm{P}$ & Mossebo et al. (2007) \\
\hline Coriolopsis telfarii (Mont.) Ryv. & $(+)$ & $\mathrm{B}$ & + & ++ & - & + & + & $\mathrm{L}, \mathrm{P}, \mathrm{T}$ & This study \\
\hline Cymatoderma elegans Jungh & +++ & $\mathrm{W}$ & +++ & +++ & ++ & $(+)$ & - & $\mathrm{L}, \mathrm{T}$ & This study \\
\hline Datronia caperata (Berk) Murr. & ++++ & $\mathrm{W}$ & / & 1 & 1 & 1 & 1 & & This study \\
\hline Earliella scabrosa (Pers.) Gilbn. \& Ryv & ++++ & W & ++ & +++ & $++(+)$ & $+(+)$ & ++ & $\mathrm{L}, \mathrm{P}, \mathrm{T}$ & Mossebo et al. (2007) \\
\hline Echinocheate brachyporus (Mont.) Ryv. & ++++ & $\mathrm{W}$ & ++++ & +++ & ++ & ++ & +++ & $\mathrm{L}, \mathrm{P}, \mathrm{T}$ & This study \\
\hline Flabellophora obovata (Jungh.) Nunez \& Ryv. & + & $\mathrm{W}$ & ++ & +++ & - & + & $+++(+)$ & $\mathrm{L}, \mathrm{P}, \mathrm{T}$ & This study \\
\hline Flavodon flavus (K1.) Ryv. & - & $\mathrm{W}$ & $(+)$ & ++ & + & - & $(+)$ & $\mathrm{L}, \mathrm{P}$ & Mossebo et al. (2007) \\
\hline Fomitopsis africana Mossebo \& Ryvarden & - & B & 1 & 1 & / & / & i & & This study \\
\hline Gloeophyllum striatum (Fr.) Murr. & - & B & - & - & - & - & - & 0 & This study \\
\hline Gyrodontium boveanum (Fr.) Hjortst & ++ & $\mathrm{W}$ & 1 & 1 & 1 & 1 & 1 & & This study \\
\hline Hexagonia speciosa (Fr.) Leif & +++ & $\mathrm{W}$ & ++++ & ++++ & ++++ & - & ++ & $\mathrm{L}, \mathrm{P}$ & This study \\
\hline Lenzites acuta Berk. & ++++ & $\mathrm{W}$ & $+++(+)$ & ++ & $+++(+)$ & + & +++ & $\mathrm{L}, \mathrm{P}, \mathrm{T}$ & This study \\
\hline Lignosus dimiticus Ryv. & +++ & W & i & 1 & i & 1 & / & & This study \\
\hline Microporus affinis (Nees \& Blume: $\mathrm{Fr}$ ) Kunth & ++++ & $\mathrm{W}$ & ++ & ++++ & $+++(+)$ & - & ++ & $L, P$ & Mossebo et al. (2007) \\
\hline Microporus xanthopus (Fr.) Kunth & ++++ & $\mathrm{W}$ & i & 1 & i & 1 & 1 & & This study \\
\hline Mycorrhaphium africanum Mossebo \& Ryvarden & ++++ & W & 1 & +++ & ++ & - & - & $\mathrm{L}$ & This study \\
\hline Nigroporus vinosus (Berk.) Murril & +++ & W & 1 & ++++ & + & - & ++++ & $\mathrm{L}, \mathrm{P}$ & This study \\
\hline Perenniporia alboferruginea D. Cony & ++++ & $\mathrm{W}$ & I & / & 1 & 1 & 1 & & This study \\
\hline Perenniporia centrali-africana Cony \& Mossebo & ++++ & $\mathrm{W}$ & / & 1 & 1 & l & 1 & & This study \\
\hline Perenniporia djaensis Cony \& Mossebo & ++++ & $\mathrm{W}$ & 1 & 1 & 1 & i & 1 & & This study \\
\hline Perenniporia martia (Berk) Ryv. & ++++ & $\mathrm{W}$ & i & 1 & 1 & i & 1 & & This study \\
\hline Perenniporia nigra Metsebing, Mossebo \& Ryvarden & - & $\mathrm{B}$ & +++ & ++ & - & +++ & ++++ & $\mathrm{L}, \mathrm{P}, \mathrm{T}$ & This study \\
\hline Perenniporia tephropora (Mont.) Ryv. & + & $\mathrm{W}$ & ++ & ++++ & + & ++ & - & $\mathrm{L}, \mathrm{T}$ & Mossebo et al. (2007) \\
\hline Polyporus tenuiculus (Beauv.) Fr. & - & B & $(+)$ & ++ & $(+)$ & - & - & $\mathrm{L}$ & Mossebo et al. (2007) \\
\hline Pseudofavollus cucculatus (Mont.) Pat. & +++ & W & 1 & 1 & 1 & 1 & 1 & & This study \\
\hline Pycnoporus sanguineus (Fr.) Murr. & +++ & W & ++ & ++++ & ++ & - & - & $\mathrm{L}$ & Mossebo et al. (2007) \\
\hline Rigidoporus microporus (Fr.) Overeem & $++(+)$ & W & ++ & ++++ & +++ & - & ++++ & $\mathrm{L}, \mathrm{P}$ & This study \\
\hline Rigidoporus ulmarius (Sow : Fr.) Imazeki & - & $\mathrm{B}$ & + & + & - & - & - & $\mathrm{L}$ & This study \\
\hline Rigidoporus vinctus (Berk) Ryvarden & +++ & $\mathrm{W}$ & / & / & / & / & / & & This study \\
\hline Trametes cingulata Berk & +++ & $\mathrm{W}$ & 1 & 1 & 1 & i & 1 & & This study \\
\hline Trametes cotonae (Pat. \& Har.) Ryv. & ++++ & W & +++ & ++ & ++ & + & $+(+)$ & $\mathrm{L}, \mathrm{P}, \mathrm{T}$ & Mossebo et al. (2007) \\
\hline Trametes elegans (Fr.) Fr. & ++++ & W & $(+)$ & +++ & $(+)$ & +++ & ++ & $\mathrm{L}, \mathrm{P}, \mathrm{T}$ & Mossebo et al. (2007) \\
\hline Trametes hirsuta (Wulfen) Pilat & ++++ & W & 1 & 1 & 1 & / & 1 & & This study \\
\hline Trametes lactinae Berk & $++(+)$ & W & - & $+++(+)$ & ++++ & - & - & $\mathrm{L}$ & Mossebo et al. (2007) \\
\hline Trametes menziesii (Berk.) Ryv. & - & $\mathrm{B}$ & - & - & - & - & - & 0 & Mossebo et al. (2007) \\
\hline Trametes modesta (Fr.) Ryv. & - & $\mathrm{W}$ & + & + & ++++ & - & ++++ & $\mathrm{L}, \mathrm{P}$ & This study \\
\hline $\begin{array}{l}\text { Lentinaceae } \\
\text { Lentinus cladopus Lév. }\end{array}$ & $(+)$ & W & - & ++ & $+(+)$ & - & - & $\mathrm{L}$ & Mossebo et al. (2007) \\
\hline
\end{tabular}




Lentinus Cf. ciliatus
Lentinus courtetianus Har. \& Pat.
Lentinus retinervis Pegler
Lentinus sajor-caju (Fr.) Fr.
Lentinus similis Berk \& Br.
Lentinus squarrosulus Mont.
Lentinus velutinus Fr.
Lentinus villosus Klotzsch

entinus villosus Klotzsch

Podoschyphaceae

Podoschypha involuta (K1.) Imazeki

Steccherinaceae

Steccherinum ethiopicum Maas Geesteranus

Ganodermataceae

Ganoderma australe (Fr.) Pat.

HYMENOCHAETALES

Hymenochaetaceae

Phellinus gilvus (Schw.) Pat.

Phellinus pachyphloeus (Pat.) Pat.

Coltricia fragilissima (Mont.) Ryvarden

$$
\text { AGARICALES }
$$

Gymnopilus aureobrunneus (Berk. \& Curtis) Murril

$$
\text { Gymnopilus russipes Pegler }
$$

Tricholomataceae

Nothopanus hygrophanus (Mont.) Singer ex. Pegler

Oudemansiella canarii (Jungh.) Höhn.

Schizophyllaceae

Shizophyllum commune (Fr.) Fr.

$$
\text { Coprinaceae }
$$

Psathyrella yaoundeana Mossebo \& Pegler

\section{Pleurotaceae}

Pleurotus citrinopileatus Singer

Pleurotus flabellatus (Berk. \& Br. Sacc.)

Pleurotus fuscosquamulosus D. A. Reid \& Eiker

Pleurotus luteoalbus Beeli

Pleurotus pulmonarius (Fr.) Quel.

Pleurotus tuber-regium (Fr.) Fr.

\section{AURICULARIALES}

Aporpiaceae

Aporpium cameroonensis Metsebing, Mossebo \& Ryvarden BOLETALES

Serpula eurocephalus (Berk \& Blume) Cooke

Serpula eurocephalus (Berk \& Blume) Cooke Type of wood

$\begin{array}{cc}+++ & +++ \\ / & +++ \\ \text { +++ } & +++ \\ ++++ & ++ \\ +++(+) & +++ \\ ++++ & +++ \\ ++++ & +++ \\ +++ & +++\end{array}$

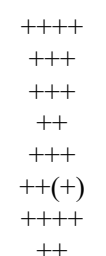

$(+)$
-
-
++
++
-
+++


TABLE II: TYPE OF Rot WiTHIN SPECIES OF THE SAME GENERA OF SOME WOOD-ROTTING BASIDIOMYCETES

(i) Some genera where all species tested display the same (W or B)

\begin{tabular}{|c|c|c|c|}
\hline & Genera & Tested species & $\begin{array}{c}\text { Type of } \\
\text { wood-rot }\end{array}$ \\
\hline \multirow{6}{*}{1 . } & \multirow{6}{*}{ Gymnopilus } & Gymnopilus aureobrunneus & $\mathrm{B}$ \\
\hline & & Gymnopilus russipes & $\mathrm{B}$ \\
\hline & & Lentinus cldopus & $\mathrm{W}$ \\
\hline & & Lentinus Cf. ciliates & W \\
\hline & & Lentinus courtetianus & W \\
\hline & & Lentinus retinervis & $\mathrm{W}$ \\
\hline \multirow[t]{5}{*}{2.} & \multirow[t]{5}{*}{ Lentinus } & Lentinus sajor-caju & $\mathrm{W}$ \\
\hline & & Lentinus similis & $\mathrm{W}$ \\
\hline & & Lentinus squarrosulus & W \\
\hline & & Lentinus velutinus & $\mathrm{W}$ \\
\hline & & Lentinus villosus & $\mathrm{W}$ \\
\hline \multirow{2}{*}{3.} & \multirow{2}{*}{ Microporus } & Microporus affinis & $\mathrm{W}$ \\
\hline & & Microporus xanthopus & $\mathrm{W}$ \\
\hline \multirow{2}{*}{4.} & \multirow{2}{*}{ Phellinus } & Phellinus gilvus & W \\
\hline & & Phellinus pachyphloeus & W \\
\hline \multirow{6}{*}{5.} & \multirow{6}{*}{ Pleurotus } & Pleurotus citrinopileatus & $\mathrm{W}$ \\
\hline & & Pleurotus flabellatus & $\mathrm{W}$ \\
\hline & & Pleurotus fuscosquamulosus & W \\
\hline & & Pleurotus luteoalbus & W \\
\hline & & Pleurotus pulmonarius & W \\
\hline & & Pleurotus tuber-regium & $\mathrm{W}$ \\
\hline
\end{tabular}

(ii) Some genera where species tested display two different types (W and B) of wood-rot
6. Coriolopsis

Coriolopsis byrsina

Coriolopsis floccosa

Coriolopsis polyzona

Coriolopsis telfarii

Perenniporia alboferruginea

Perenniporia centrali-africana

Perenniporia djaensis

Perenniporia martia

Perenniporia nigra

Perenniporia tephropora

8. Rigidoporus

Rigidoporus microporus

Rigidoporus ulmarius

Rigidoporus vinctus

Trametes cingulata

Trametes cotonae

Trametes elegans

9. Trametes

Trametes lactinae

Trametes menziesii

Trametes modesta

W

W

W

B

W

W

W

W

B

W

W

B

W

W

W

W

W

W

B

W

Remark - Results recorded in Table III show that within wood-rotting fungi, even though all species belonging to some genera display the same type of rot (W or B), species of some other genera were found to rather display different type of rot $(\mathrm{W}$ and $\mathrm{B})$ in species within the same genera.
B. Variability in the Potential Level of Enzymatic activities in Species of Some Genera of Wood-rotting Basidiomycetes 1) Variability in the potential level of activity of tyrosinase and peroxydase in some species of wood-rotting Basidiomycetes belonging to the same genera

Results presented in Table I show that in several genera considered separately, species tested in each of these genera do not always produce the same enzymes and for enzymes commonly produced, they do not always present the same level of potential activity. In fact, some species belonging to the same genera potentially produce some enzymes and others not, as the case for instance for Gymnopilus aureobrunneus, Phellinus gilvus, Pleurotus citrineopileatus and Pleurotus tuber-regium which produce tyrosinase, whereas Gymnopilus russipes, Phellinus pachyphloeus and Pleurotus pulmonarius do not produce this enzyme as shown in Table IV. It is also the case for Trametes cotonae, T. elegans, T. modesta and Rigidoporus microporus which produce peroxydase whereas Trametes lactinae, T. menziesii and Rigidoporus ulmarius do not produce it (Table IV).

2) Comparative detection level of laccases by $\alpha$-naphtol and syringaldazine

Results recorded in Table I show that laccases are comparatively the most common enzymes secreted by a very large majority (51 species out of a total of 53 tested) of species tested for these enzymes, Gloephyllum striatum and Trametes menziesii being the only species that reacted negatively (-) for laccases. These results also show that $\alpha-$ naphtol generally detects laccases better than syringaldazine as for instance for Climacodon pulcherimus, Coriolopsis telfarii, Gymnopilus aureobrunneus, Gymnopilus russipes, Perenniporia nigra and Rigidoporus ulmarius that first reacted negatively (-) with syringaldazine for the detection of laccases and it is later on $\alpha$-naphtol that reacted positively $(+)$ to detect the presence of these enzymes in the above mentioned species as shown in Table V.

TABLE III: VAriation of Potential Activity LeVel of Tyrosinase AND PeroXydase In SOME Species of Wood-RotTing Basidiomycetes BELONGING TO THE SAME GENERA

\begin{tabular}{|c|c|c|c|c|c|}
\hline \multicolumn{3}{|c|}{$\begin{array}{l}\text { Variation of the potential activity level of tyrosinase in some species } \\
\text { belonging to the same genera }\end{array}$} & \multicolumn{3}{|c|}{$\begin{array}{l}\text { Variation of the potential activity level of peroxydase in some } \\
\text { species belonging to the same genera }\end{array}$} \\
\hline Genera & Species & $\begin{array}{l}\text { Potential activity } \\
\text { level of tyrosinase } \\
\end{array}$ & Genera & Species & $\begin{array}{c}\text { Potential activity } \\
\text { level of peroxydase }\end{array}$ \\
\hline \multirow{2}{*}{ Gymnopilus } & $\begin{array}{l}\text { Gymnopilus } \\
\text { aureobrunneus }\end{array}$ & +++ & \multirow{5}{*}{ Trametes } & Trametes cotonae & $+(+)$ \\
\hline & Gymnopilus russipes & - & & Trametes elegans & ++ \\
\hline \multirow{3}{*}{ Phellinus } & Phellinus gilvus & +++++ & & Trametes lactinae & 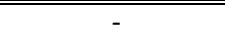 \\
\hline & $\begin{array}{c}\text { Phellinus } \\
\text { pachyphloeus } \\
\end{array}$ & - & & Trametes menziesii & - \\
\hline & $\begin{array}{c}\text { Pleurotus } \\
\text { citrineopileatus }\end{array}$ & +++ & & Trametes modesta & ++++ \\
\hline Pleurotus & $\begin{array}{c}\text { Pleurotus } \\
\text { pulmonarius } \\
\text { Pleurotus tuber- } \\
\text { regium } \\
\end{array}$ & $\begin{array}{l}- \\
+\end{array}$ & Rigidoporus & $\begin{array}{c}\text { Rigidoporus } \\
\text { microporus } \\
\text { Rigidoporus } \\
\text { ulmarius } \\
\end{array}$ & $\begin{array}{c}++++ \\
- \\
\end{array}$ \\
\hline
\end{tabular}

Remark - The level of activity of tyrosinase and peroxidase (Table IV) shows more or less important variations between species of some genera, whereby these species belonging to same genera show varying potential level $(+,++,+++,++++)$ of activities of these two enzymes, whereas other species of the same genera show no sign (-) of activity of the same enzymes. Therefore, our results lead to the conclusion that the presence $(+,++,+++,+++)$ or absence $(-)$ of activity of peroxidase and tyrosinase can from now onwards also be used as an enzyme linked taxonomic criteria to distinguish between species of some genera. 
TABLE IV: COMPARATIVE DETECTION LEVEL OF LACCASES BY ALPHA-NAPHTOL AND SyRINGALDAZINE IN SOME SPECIES OF WOOD-ROTTING BASIDIOMYCETES

\begin{tabular}{ccccc}
\hline \hline $\mathrm{N}^{\circ}$ & Species name & & \multicolumn{2}{c}{ Detection of laccases by $\alpha$-naphtol and syringaldazine } \\
\cline { 3 - 5 } 1. & Climacodon pulcherimus & - & $\alpha$-naphtol & Conclusion \\
2. & Coriolopsis telfarii & - & ++ & $\alpha$-naphtol detects laccases \\
3. & Gymnopilus aureobrunneus & - & $++(+)$ & + \\
4. & Gymnopilus russipes & - & ++ & better than syringaldazine in some species of \\
5. & Perenniporia nigra & - & + & wood-rotting Basidiomycetes. \\
6. & Rigidoporus ulmarius & - & & \\
\hline \hline
\end{tabular}

Remark - Results recorded in Table V show that if a negative result (-) occurs during detection test of laccases in a wood-rotting fungus using syringaldazine, $\alpha$-naphtol must also be used as a differential test before concluding whether the species produces laccases or not.

3) Comparative detection level of unspecific polyphenol oxidases by guaiac and guaiacol

About the detection of unspecific polyphenol oxidases using guaiac and guaiacol as substrates, here also were major differences noticed in the sensitiveness of both reagents for some species of wood rotting fungi. For instance, Perenniporia nigra, Polyporus tenuiculus, Rigidoporus ulmarius, Serpula eurocephalus and Trametes modesta reacted negatively (-) to guaiac and positively $(+)$ to guaiacol for the detection of these enzymes as shown in Table VI. On the contrary, Trametes lactinae and Lentinus cladopus were positive $(+)$ to guaiac and negative (-) to guaiacol for the detection of the same oxidation enzymes.

TABLE V: COMPARATIVE DETECTION LEVEL OF UNSPECIFIC POLYPHENOL OXIDASES BY GUAIAC AND GUAIACOL IN SOME SPECIES OF WOODROTTING BASIDIOMYCETES

\begin{tabular}{|c|c|c|c|c|}
\hline \multirow[t]{2}{*}{$\mathrm{N}^{\circ}$} & \multirow[t]{2}{*}{ Species name } & \multicolumn{2}{|c|}{$\begin{array}{c}\text { Detection of unspecific } \\
\text { polyphenol oxidases by } \\
\text { guaiac and guaiacol }\end{array}$} & \multirow[t]{2}{*}{ Conclusion } \\
\hline & & Guaiac & Guaicol & \\
\hline 1. & Lentinus cladopus & $(+)$ & - & Detection of \\
\hline 2. & $\begin{array}{l}\text { Perenniporia } \\
\text { nigra }\end{array}$ & - & +++ & $\begin{array}{l}\text { unspecific } \\
\text { polyphenol }\end{array}$ \\
\hline 3. & $\begin{array}{l}\text { Polyporus } \\
\text { tenuiculus }\end{array}$ & - & $(+)$ & $\begin{array}{l}\text { oxidases can } \\
\text { show highly }\end{array}$ \\
\hline 4. & $\begin{array}{l}\text { Rigidoporus } \\
\text { ulmarius }\end{array}$ & - & + & $\begin{array}{l}\text { contrasting } \\
\text { results in some }\end{array}$ \\
\hline 5. & $\begin{array}{c}\text { Serpula } \\
\text { eurocephalus }\end{array}$ & - & + & $\begin{array}{l}\text { species of wood- } \\
\text { rotting }\end{array}$ \\
\hline 6. & Trametes lactinae & $++(+)$ & - & $\begin{array}{l}\text { Basidiomycetes } \\
\text { depending on the }\end{array}$ \\
\hline 7. & Trametes modesta & - & + & substrate used. \\
\hline
\end{tabular}

Remark - Based on the results recorded in Tables II, V and VI showing the highly contrasting level of detection of some enzymes in some wood rotting fungi when different substrates are used, it appears absolutely necessary, wherever indicated, to use several substrates with different chemical sensitivities when resorting to spot tests to detect the existence of an enzyme and its potential activity level in a fungal species.

\section{Enzymatic Activity and Taxonomic Groupings}

The maximum level of enzymes potential oxidizing activity of each of the 53 species tested to this aim is presented in Table I. These results reveal that tincture of guaiac and guaiacol together detected unspecific polyphenol oxidase activities in 51 out of the 53 species tested, Gloephyllum striatum and Trametes menziezii being the two species showing no sign (-) of enzymatic activity. As said earlier, laccase appears as the most common enzyme secreted by 51 out of 53 species tested for this enzyme which was identified at varying levels $(+,++,+++,++++)$ of potential activities in the 51 species. Out of a total of 53 species tested for the presence of laccase, tyrosinase and peroxidase, results recorded led to the following 6 taxonomic groupings:

Group I. Species with laccase, tyrosinase and peroxidase activities $(\mathrm{L}, \mathbf{P}, \mathbf{T})$

Coriolopsis telfarii, Earliella scabrosa, Echinocheate brachyporus, Flabellophora obovata, Ganoderma australe, Lentinus cf. ciliatus, Lentinus retinervis, Lentinus sajor-caju, Lentinus similis, Lentinus velutinus, Lenzites acuta, Oudemensiella canarii, Perenniporia nigra, Phellinus gilvus, Pleurotus citrineopileatus, Pleurotus flabellatus, Pleurotus fuscosquamulosus, Pleurotus luteoalbus, Pleurotus tuberregium, Serpula eurocephalus, Trametes cotonea, Trametes elegans.

Group II. Species with laccase and peroxidase, but no tyrosinase activity $(\mathrm{L}, \mathrm{P})$

Aporpium cameroonensis, Climacodon pulcherimus, Coriolopsis polyzona, Flavodon flavus, Gymnopilus russipes, Hexagonia speciosa, Lentinus courtetianus, Lentinus squarrosulus, Lentinus villosus, Microporus affinis, Nigroporus vinosus, Nothopanus hygrophanus, Phellinus pachyphloeus, Pleurotus pulmonarius, Podoscypha involuta, Psathyrella yaoundeana, Rigidoporus microporus, Schizophyllum commune, Stecherinum ethiopicum, Trametes modesta.

Group III. Species with laccase and tyrosinase, but no peroxidase activity $(\mathrm{L}, \mathrm{T})$

Gymnopilus aureobrunneus, Cymatoderma elegans, Perenniporia tephropora.

Goup IV. Species with laccase, but no tyrosinase and no peroxidase activity $(\mathbf{L})$

Lentinus cladopus, Mycorrhaphium africanum, Polyporus tenuiculus, Pycnoporus sanguineus, Rigidoporus ulmarius, Trametes lactinea.

Group V. Species with tyrosinase, but no laccase, and no peroxidase activity $(\mathrm{T})$

No species recorded.

Group VI. Species with no laccase, no tyrosinase and no peroxidase activity (0)

Gloephyllum striatum, Trametes menziezii.

D. Lists of Species Tested with Potentially Strong $(++++$ or +++$)$ Enzymatic and Oxidation Activity, Classified according to Types of Enzymes Produced with Their Detection Substrates

Following the whole enzymatic tests carried out as presented in Table I, lists of species showing potentially strong $(+++$ or ++++$)$ enzymatic and oxidation activities were established. Besides the active role of these species in wood oxidation and decay in the nature, thereby contributing to forest clearing and opening way for forestry regeneration, they could potentially be used in industrial and sanitation 
processes as mentioned in the "Introduction" including biopulping processes in paper making industries, waste water treatment and soil remediation, food processing and browning reactions and some other biotechnological processes such as the production and purification of enzymes for other uses. In the following lists (Tables VII, VIII and IX), species with potentially strong $(+++$ or ++++$)$ enzymatic and oxidation activities are classified according to the type of enzyme(s) produced with their detection substrates:

TABLE VI: SPECIES With A POTENTIALLY STRONG (+++ OR ++++$)$ ACTIVITY OF UNSPECIFIV POLYPHENOL OXIDASES DETECTED BY GUAIAC

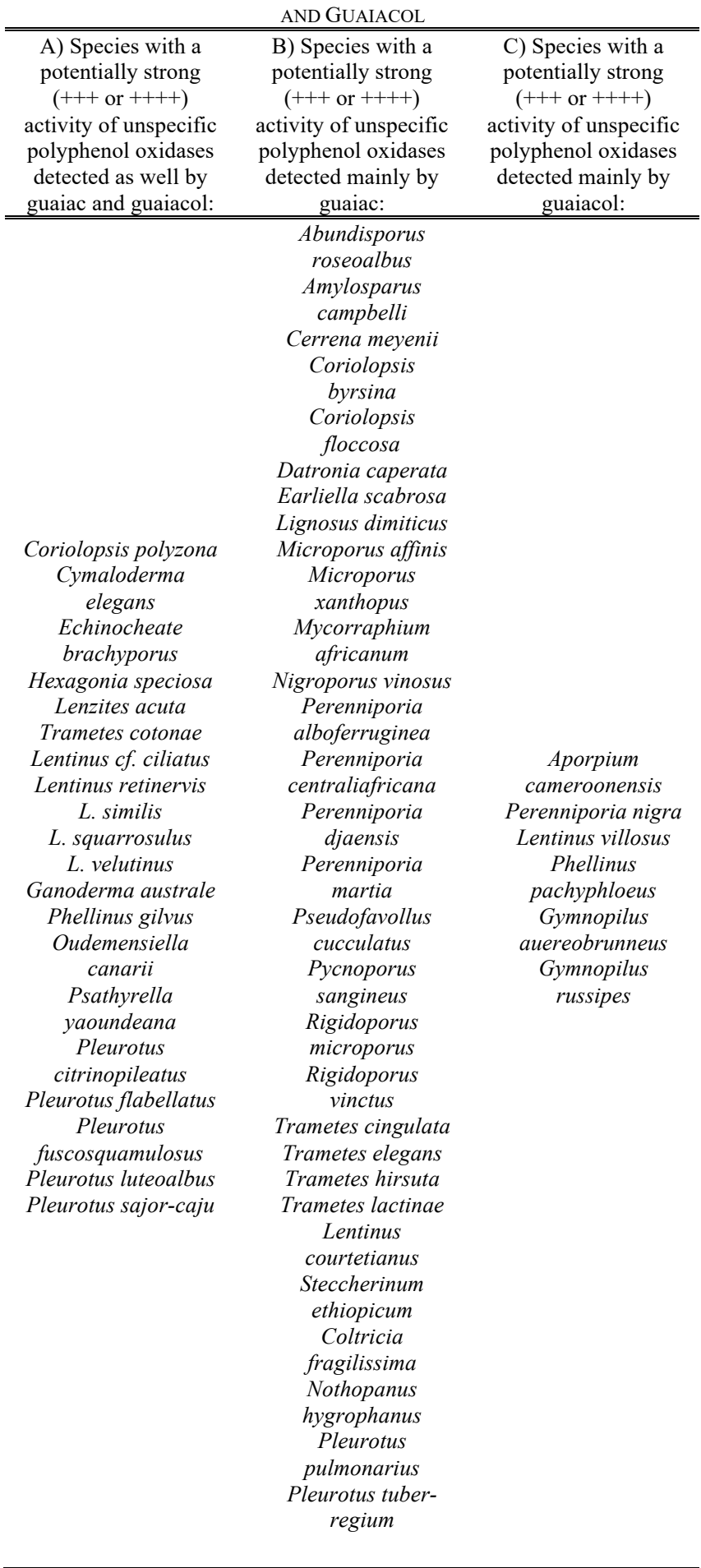

TABLE VII: SPECIES WITH A POTENTIALLY STRONG (++++ OR +++) ACTIVITY OF LACCASES DETECTED BY ALPHA-NAPHTOL AND SYRINGALDAZINE

E) Species with a F) Species with a

D) Species with a potentially strong $(+++$ or ++++$)$ activity of laccases detected as well by $\alpha$-naphtol and syringaldazine: $(+++$ or ++++$) \quad(+++$ or ++++$)$ activity of activity of

laccases detected laccases detected mainly by $\alpha-\quad$ mainly by naphtol: syringaldazine:

Aporpium

cameroonensis

Coriolopsis polyzona

Earliella scabrosa

Flabellophora obovata

Hexagonia speciosa

Microporus affinis Rigidoporus microporus

Trametes lactinae

Lentinus cf. ciliatus

L. courtetianus

L. retinervis

Lentinus similis

L. squarrosulus

L. velutinus

Podoscypha involuta

Phellinus gilvus

Oudemensiella canarii

Pleurotus

citrinopileatus

Pleurotus

flabellatus

Pleurotus

fuscosquamulosus

Pleurotus tuberregium

TABLE VIII: SPECIES WITH A POTENTIALLY STRONG $(+++$ OR ++++$)$ ACTIVITY OF TYROSINASE DETECTED BY P-CRESOL AND THOSE WITH THE SAME LEVEl OF ACTIVITY OF PEROXIDASE DETECTED BY $\mathrm{H}_{2} \mathrm{O}_{2}$ /PYROGALLOL

\begin{tabular}{cc}
\hline \hline G) Species with a potentially & H) Species with a potentially \\
strong (+++ or ++++$)$ activity of & strong $(+++$ or ++++ ) activity of \\
tyrosinase detected by p-cresol: & peroxidase detected by \\
& $\mathrm{H}_{2} \mathrm{O}_{2} /$ Pyrogallol: \\
\hline \hline & Echinocheate brachyporus \\
Flabellophora abovata \\
Perenniporia nigra & Lenzites acuta \\
elegans & Nigroporus vinosus \\
Lentinus similis & Perenniporia nigra \\
Lentinus velutinus & Rigidoporus microporus \\
Phellinus gilvus & Trametes modesta \\
Gymnopilus aureobrunneus & Lentinus similis \\
Pleurotus citrineopileatus & Lentinus squarrosulus \\
Pleurotus flabellatus & Steccherinum ethiopicum \\
Pleurotus fuscosquamulosus & Ganoderma australe \\
& Phellinus gilvus \\
& Psathyrella yaoundeana \\
& Pleurotus citrineopileatus \\
& Pleurotus flabellatus \\
& Pleurotus fuscosquamulosus \\
& Pleurotus luteoalbus \\
& Pleurotus pulmonarius \\
& Pleurotus tuber-regium \\
\hline
\end{tabular}

\section{E. Wood Substrate Specificity to Wood-Rotting Fungi}

Results of the first ever inventory carried out on living or dead wood in some forestry areas of Cameroon combined to other field data obtained from some few other countries of tropical Africa in a survey to find out which species of 
Polyporales grow on which species of wood are presented in Table X. These provisional results show that, whereas some Polyporales were found only on a single wood species, some other lignicolous species serve as substrate for several different Polyporales including for instance Terminalia superba on which six (6) species of polyporales were collected, three (3) on Erthrophleùm guineense, two (2) on Ricinodendron heudelotii and two (2) others on Trïplochiton scleroxylon as presented in Table X. In total about 20 species of wood fungi were collected during the survey and distributed in 3 families of Polyporales including the Ganodermataceae, Hymenochaetaceae and Polyporaceae, the latter being far away the most dominant family as shown in Table X.

With regard to the study of substrate specificity which aimed at finding out the existence or not of a specificity between Polyporales and tree wood species on which they grow, these results based on a limited number of trees investigated led to the preliminary conclusion that although some few tree species may serve as hosts for only a single species of polyporales (examples : Mitragynia dilata for Flabellophora obovata; Gilbertiodendron brachystegioides for Trametes modesta; Distemonanthus benthamianus for Serpula eurocephalus; Mansonia altissima for Donkia pulcherimus), there is rather a greater tendency of finding several species of Polyporales growing on different species of wood as well as the same species of wood hosting several species of Polyporales. However, on this issue, a much larger inventory including a greater number of tree species growing in various tropical ecosystems (urban, savannah, forestry) is necessary in order to come out with a final conclusion.

\begin{tabular}{|c|c|c|}
\hline Trees wood substrates and belonging family & Species of Polyporales collected on wood & Family of Polyporales \\
\hline $\begin{array}{l}\text { Mitragyna dilata (Aubrev \& Pellegr) Baya } \\
\text { (Rubiaceae) }\end{array}$ & $\begin{array}{c}\text { Flabellophora obovata (Jungh) Comer } \\
\text { Stereum ostrea (Blume \& T. Nees) Fr. } \\
\text { Trametes sp } \\
\text { Polyporus tenuiculus (P. Beaux.) Fr. } \\
\text { Trametes lactinae (Berk.) Pat. } \\
\text { Coriolopsis polyzona (Pers.) Ryv. } \\
\text { Hexagonia glaber (Beauv.) Ryvarden }\end{array}$ & Polyporaceae \\
\hline $\begin{array}{l}\text { Gilbertiodendron brachystegioides (Harms) J. } \\
\text { Léonard (Fabaceae- (s/f: Caesalpinioideae) }\end{array}$ & Trametes modesta (Fr.) Ryv. & Polyporaceae \\
\hline $\begin{array}{l}\text { Distemonanthus benthamianus Baill. } \\
\text { (Caesalpinioideae) }\end{array}$ & Serpula eurocephalus (Berk \& Blume) Cooke (i) & \\
\hline $\begin{array}{l}\text { Mansonia altissima (A. Chev.) A. Chev. } \\
\text { (Fabaceae- (s/f : Caesalpinioideae) }\end{array}$ & Donkia pulcherrimus (Berk. \& Curt.) Nikolayeva & Polyporaceae \\
\hline $\begin{array}{l}\text { Erthrophleùm guineense (Guill. \& Perr.) } \\
\text { Brenan (Fabaceae) }\end{array}$ & $\begin{array}{l}\text { Ganoderma australe (Fr.) Pat. } \\
\text { Ganoderma resinaceum Boudier } \\
\text { Trametes laetinae (Berk.) Pat. }\end{array}$ & $\begin{array}{c}\text { Ganodermataceae } \\
\text { Polyporaceae }\end{array}$ \\
\hline $\begin{array}{l}\text { Ricinodendron heudelotii (Baill.) Pierre \& } \\
\text { Pax. (Euphorbiaceae) }\end{array}$ & $\begin{array}{l}\text { Phellinus pachyphloeus (Pat.) Patueus } \\
\text { Rigidoporus ulmarius (Sowerby. Fe) Imazeki }\end{array}$ & $\begin{array}{l}\text { Hymenochaetaceae--- } \\
\text { Polyporaceae }\end{array}$ \\
\hline $\begin{array}{c}\text { Klainedoxa gabonensis Pierre ex Engl. } \\
\text { (Irvingiaceae) }\end{array}$ & Ganoderma australe (Fr.) Pat. & Ganodermataceae \\
\hline $\begin{array}{c}\text { Trïplochiton scleroxylon K. Schum. } \\
\text { (Sterculiaceae) }\end{array}$ & $\begin{array}{c}\text { Ganoderma chalceum Cooke } \\
\text { Phylloporia chrystata (Berk.) Ryvarden (i) }\end{array}$ & $\begin{array}{c}\text { Ganodermataceae } \\
\text { Polyporaceae }\end{array}$ \\
\hline $\begin{array}{c}\text { Holoptelea grandis (Hutch.) Mildbr. } \\
\text { (Ulmaceae) }\end{array}$ & Rigidoporus ulmarius (Sow. Fr.) Imazeki & Polyporaceae \\
\hline $\begin{array}{c}\text { Celtis Adolfi-Friderici Engl. Diana } \\
\text { (Ulmaceae) }\end{array}$ & Phellinus pachyphloeus (Pat.) Pat. & Hymenochaetaceae \\
\hline Undetermined dry liana in decay & $\begin{array}{l}\text { Earlielal scabrosa (Pers.) Gilb. \& Ryv. } \\
\text { Ganoderma australe (Fr.) Pat. }\end{array}$ & $\begin{array}{c}\text { Polyporaceae } \\
\text { Ganodermataceae }\end{array}$ \\
\hline Alstonia boonei De Wild. (Apocynaceae) & Ganoderma sp. & Ganodermataceae \\
\hline
\end{tabular}

\section{DiscusSION}

A. Determination of Type of Wood-decay and Detection of Potential Level of Unspecific Polyphenol Oxidases by Tincture of Guaiac and Guaiacol

About the type of rot caused by wood-decay Basidiomycetes, the data recorded in Table I show a clear predominance of white $\operatorname{rot}(\approx 85 \%)$ on brown $\operatorname{rot}(\approx 15 \%)$. These figures are globally in accordance with those of most authors who carried out studies (Mossebo et al. 2007; Stalpers, 1978; Nakasone, 1990; David, 1980; Gilbertson, 1980; Gilbertson \& Ryvarden, 1986), or simply reported (Ryvarden \& Johansen, 1980; Gilbertson \& Ryvarden, 1987; Ryvarden, 1991) on type of wood decay caused by fungi and generally concluded that the number of brown rot fungi is 
remarkably smaller compared to that of white rot fungi.

Concerning unspecific polyphenoloxidases as detected by guaiac and guaiacol, these substrates showed according to species, more or less important differences in their ability to detect these enzymes as presented in Table VI. Agerer et al., (2000), also noticed such differences when studying extracellular oxidase activities in some ectomycorrhizal and saprophytic fungi, which he explained by the high heterogeneity of phenoloxidases which are composed of many different phenolic compounds with different oxidizing capabilities according to the substrate (guaiac, gallic acid agar, tannic acid agar) used. Elsewhere, in order to explain these differences, Cairney \& Burke, (1998) evoked the possible role of iron-radicals in culture media that could cause "false positive" reactions though their findings were later on amended by Agerer et al., (2000).

Tincture of guaiac provides one of the best illustrations of the above-mentioned inconsistencies according to species. Here, the cases of Gloeophyllum striatum, Polyporus tenuiculus and Trametes menziesii based on our results compared to those of previous studies are worth mentioning. These three species which were taxonomically determined by Ryvarden (pers. comm.) tested negative with guaiac (Table I), thereby determining brown rot. Two of the three species including Polyporus tenuiculus and Trametes menziesii tested positive in other studies and were consequently identified as white rotters as reported by Mswaka \& Magan, 1998 for T. menziesii and Giltbertson \& Ryvarden (1987) reporting works of other authors for $P$. tenuiculus. However, concerning the specific case of $T$. menziesii of which two different strains from Cameroon tested negative with guaiac (absolutely no shift in color was observed with the first strain and very faint traces of blue appeared about an hour after putting tincture of guaiac drops on actively growing mycelium of the second strain, meaning unequivocally a negative result), our results are rather in correlation with an additional cross-check experiment carried out by Mswaka \& Magan, 1998, who in a phenoloxidase and lignin biodegradation assay noticed the inability of $T$. menziesii to degrade lignin, the general rule being that fungi that cause white rot are able to degrade lignin. The authors (Mswaka \& Magan, 1998) however recognized the contradiction between their result on lignin biodegradation assay with T. menziezii and their guaiac test, the assay correlating with our guaiac test result on this species.

Besides the common explanations (heterogeneity of phenolic compounds in phenoloxidases, possible "false positives" due to iron-radicals etc.) usually given by authors for such controversial results and concerning the specific case of tincture of guaiac, we noticed that these differences in guaiac test results could also arise from various interpretations of two important parameters that determine positive and negative results, namely the precise moment at which the shift in color to blue occurs during drop-test on mycelial cultures, and the blueing intensity observed. In fact Nobles, (1958) who first introduced this substrate mentioned that the presence of phenoloxidases in mycelial cultures is determined by a rapid blueing and that a faint late-appearing blue should be regarded as a negative result. However, except for clearly positive tests identified by a rapid blueing occurring during dropping on mycelium, or clearly negative tests recorded when absolutely no shift in color occurs no matter how long the time, the author did not precisely indicate at which time-limit and which blueing intensity the intermediate results should be considered positive or negative. Considering that tincture of guaiac reacts quite differently on mycelial cultures as far as time, blueing intensity and fungal species are concerned, and furthermore that no additional investigation has so far been carried out to clarify these guaiac test-parameters, this has undoubtedly led to cases of misinterpretations by different authors of what should be considered positive or negative to guaiac. This could therefore be the explanation for the above-mentioned controversial results concerning guaiac tests in some species.

However, still concerning polyphenoloxidase activities identified by guaiac, the results recorded in some of our strains are in agreement with those of previous studies carried out by other authors. To be noted here is the case of Trametes elegans that tested positive with this substrate as did the collection of Mswaka \& Magan, 1998. The positive guaiac test of Irpex stereoides investigated by the same authors compared to the same result recorded in our collection of (Flavodon (Irpex) flavus (Table II) as well as results recorded in Table III for all species tested in genera Gymnopilus, Lentinus, Microporus, Phellinus and Pleurotus are in agreement with the remarks of David, 1980 and Gilbertson, 1980 who as several other authors noted a correlation between morphologically defined genera and their type of rot. However, on this issue precisely, Ryvarden, (1991) reporting on the works previously carried out by Gilbertson \& Ryvarden, 1986 and Gilbertson \& Ryvarden, 1987 pointed out the existence amongst some genera of both white and brown rot species, as illustrated in our results presented in Table III and particularly for species tested in genera Coriolopsis, Perenniporia, Rigidoporus and Trametes.

About the above-mentioned intra-generic differences in the oxidizing activity level of enzymes of some species as shown in Table III and particularly for species tested in genera Coriolopsis, Perenniporia, Rigidoporus and Trametes, they could be explained by the varying capability of these species to produce oxidases as postulated by Agerer et al., (2000), who observed the same differences in the genus Cortinarius, where $C$. infractus tested strongly positive with guaiac and $C$. odorifer consistently negative. The author found the same trend in the genus Amanita, where Amanita subg. Amanitopsis and Amanita subg. Amanitopsis tested respectively positive and negative with the same substrate.

Our results on Pycnoporus sanguineus testing positive (Table I) with guaiac are in agreement with those of Mswaka \& Magan, 1998, but it is worth noting here that for tincture of guaiac, as well as for syringaldazine and $\alpha$-naphtol, we observed the shift in color that determined positive tests only on the red to reddish (color of mature fructifications : 9A7, 9A8, 9B8, 9C8, 10A8, 10B8, 10C8 in Kornerup \& Wanscher, (1978)) parts of the mycelial cultures showing microfructification growths and never on the white part of the mycelium, where color change usually occurs in most species. This phenomenon, peculiar to this species and never mentioned before in any other study, could be explained by the phenoxazin-3-one pigments such as cinnabarin, cinnabarinic acid and tramesanguin already known to be produced in fructifications of this species as reported by 
Sullivan \& Henry, (1971) and that could be involved in complex reactions leading to the oxidation of the abovementioned substrates.

\section{B. Laccase Activity Detected by a-naphtol and Syringaldazine}

Results recorded in Table I show that laccases are comparatively the most common enzymes secreted by the very large majority (51 species out of a total of 53 tested or $96,22 \%$ of the total tested) of species tested for these enzymes. These figures are proportionately in agreement with Messerschmidt, (2010) who affirms that "laccase is very abundant in fungi" and plays a role in lignin degradation, sporulation, pigment production and pathogenesis.

$\alpha$-naphtol and syringaldazine which are the substrates used for laccases detection showed more or less important differences in their ability to detect this enzyme as presented in Table $\mathrm{V}$ for some wood rotting Basidiomycetes including Climacodon pulcherimus, Coriolopsis telfarii, Gymnopilus aureobrunneus, Gymnopilus russipes, Perenniporia nigra, and Rigidoporus ulmarius. In fact, in spite of some few cases where these two substrates detected laccase at the same potential level of activity $(+,++,+++,++++)$, the above mentioned inconsistencies (Table V) could be explained, as for unspecific polyphenol oxidases, by the possible role of iron radicals in culture media and the varying capacities of investigated species to produce laccase that probably oxidises $\alpha$-naphtol and syringaldazine in different manners. This last hypothesis is supported by the existence of multiple forms of laccases as postulated by several authors including Blaich \& Esser, (1975), who in a study carried out on 15 wood-fungi by analytical isoelectric focusing (IEF) noticed that most of these fungi exhibit a pattern of 6 to 10 extra- and intracellular laccases divided into two groups, laccase A complex reacting at PH 3-4 and laccase B complex at PH 5-8, with quantitative differences in their ability to oxidize various phenolic substrates. Marr, 1979 further reported multiple forms of laccases and tyrosinases, each form (isoenzyme) exhibiting a characteristic substrate-specific pattern.

\section{CONCLUSION}

In conclusion, based on the results recorded on the one hand in Table I where 46 out of 72 species were investigated for the first time as far as type of wood-rot is concerned, and on the other hand in Tables II, V and VI showing the highly contrasting level of detection of some enzymes in some species when different substrates are used, it appears absolutely necessary, where indicated, to use several substrates with different chemical sensitivities when using spot tests to detect the existence of an enzyme and its potential activity level in a fungal species.

Additionally, the presence $(+,++,+++,++++)$ or absence (-) of enzymatic activities in species of some genera of wooddecay fungi can from now onwards be used as an enzyme linked taxonomic criteria to distinguish between species of these genera.

\section{ACKNOWLEDGEMENTS}

We are very grateful to the French Research Institute for
Development (IRD) who under his SEP2D ("Sud Expert Plantes Développement Durable") programme, awarded us a research grant (SEP2D N ${ }^{\circ}$ AAP3-5 and Convention $\mathrm{N}^{\circ} 307$ $726 / 00$ ) that was partly invested to purchase the laboratory reagents and other material necessary to carry out this research work, the other part covering the expenses for the field work for sampling and collecting the biological material used for the spot tests.

\section{REFERENCES}

Agerer, R., Schloter, M., Hahn, C. (2000). Fungal enzymatic activity in fruitbodies, Nova Hedwigia, 71: 315-336.

Ambit, R. T., \& Mossebo, D. C. (2015). The first African record of Artolenzites acuta comb. nov. (Basidiomycota, Polyporaceae), Mycosphere, 6(3): 280-289.

Bavendamm, W. (1928). Über das Vorkommen und den Nachweis von oxydasen bei holzzerstörenden Pilzen, Zeitung der Pflanzenkrankheit und Pflanzenschutz, 38: 257-276. German.

Blaich, R., \& Esser, K. (1975). Function of Enzymes in Wood Destroying Fungi II. Multiple forms of laccase in white rot fungi, Archives of Microbiology, 103: 271-277.

Boidin, J. (1951). Recherche de la Tyrosinase et de la Laccase chez les Basidiomycètes en culture pure. Milieux différentiels. Intérêt systématique, Revue de Mycologie, 16, 173-197. French.

Boidin, J., Lanquetin, P. (1983). Basidiomycètes Aphyllophorales Epitheloïdes Etales. Mycotaxon, 16: 461-499.French.

Boidin, J., Lanquetin, P. (1995). Sur quelques corticiés (Basidiomycotina) de l'Ethiopie, Cryptogamie-Mycologie, 16(2): 85-89. French.

Cairney, J. W. G., \& Burke, R. M. (1998). Do ecto- and ericoid mycorrhizal fungi produce peroxidase activity, Mycorrhiza, 8: 1-65.

Charbonnel, J. (1995). Les réactifs mycologiques. Tome 1. Les Réactifs macrochimiques, Edité par l'auteur Jacques Charbonnel, Langeas. French.

David, A. (1980). Etude du genre Tyromyces sensu lato: Répartition dans les genres Leptoporus, Spongiporus et Tyromyces sensu stricto, Bulletin Mensuel de la Société Linnéene de Lyon, 49: 6-56. French.

Gilbertson, R. L. (1980). Wood rotting fungi of North America, Mycologia, 72(1): $1-49$.

Gilbertson, R. L. (1981). North American wood-rotting fungi that cause Brown rots, Mycotaxon, 12: 372-416.

Gilbertson, R. L., \& Ryvarden, L. (1986). North American Polypores, Fungiflora, 1: 433.

Gilbertson, R. L., \& Ryvarden, L. (1987). North American Polypores, in Fungiflora, 2: 437-885.

Harkin, J. M., \& Obst, J. R. (1973). Syringaldazine, an Effective Reagent for detecting Laccase and Peroxidase in Fungi, Experientia, 29(4): 381387.

Harkin, J. M., Larsen M. J., Obst, J. R. (1974). Use of syringaldazine for detection of laccase in sporophores of wood rotting fungi, Mycologia, 66: 469-476.

Käärik, A. (1965). The identification of the mycelia of wood-decay fungi by their oxidation reactions with phenolic compounds, Studia Forestalia Suecica, 31: 3--81.

Kornerup, A., \& Wanscher, J. H. (1978) Methuen Handbook of colour, Eyre Methuen, 3rd Ed., London, 252 pp.

Kreisel, H., \& Schauern, F. (1987). Methoden des mykologischen Laboratoriums, Gustav Fisher Verlag, Stuttgart, New York, 181. German.

Marr, C. D. (1979). Laccase and tyrosinase oxidation of spot test reagents, Mycotaxon, 9: 244-276.

Marr, C. D., Grund, D. W., Harrison, K. A. (1986). The taxonomic potential of laccase and tyrosinase spot tests, Mycologia, 78(2): 1696-184.

Mayer, A. M. (2006). Polyphenol oxidases in plant and fungi: Going places, A review. Phytochemistry, 67: 2318-2331.

Messerschmidt, A. (2010). Enzymes and Enzymes Mechanisms. Comprehensive Natural Product II, Chemistry and Biology, 8: 489545.

Metsebing, B. P., Tsigaing, T. F., Oba, R., Mossebo, D. C., Ryvarden, L. (2019). Studies in Aphyllophorales of Africa 33. Two new poroid species from Cameroon, Synopsis Fungorum, 39: 72-75.

Mossebo, D. C., \& Ryvarden, L. (1997). Fomitopsis africana nov. sp. (Polyporaceae, Basidiomycotina), Sydowia, 49(2): 147-149. Latin. 
Mossebo, D. C. (2002). Growth of wood inhabiting Lentinus species from Cameroon in laboratory culture, Mycologist, 16(4): 168-171.

Mossebo, D. C., \& Ryvarden, L. (2003). The genus Mycorrhaphium in Africa, Mycotaxon, 88: 229-232.

Mossebo, D. C., Njouonkou, A. L., Courtecuisse, R., Akoa, A. (2007). Enzymatic activities and decay characteristics in some wood-rotting Basidiomycetes from Cameroon and determination of the timedependant activity of syringaldazine in spot tests, CryptogamieMycologie, 28(2): 107-121.

Mswaka, A. Y., Magan, N. (1998). Wood degradation, and cellulase and ligninase production, by Trametes and other wood-inhabiting basidiomycetes from indigenous forests of Zimbabwe, Mycological Research, 102(11): 1399-1404.

Nakasone, K. K. (1990). Cultural studies and identification of wood inhabiting Corticiaceae and selected Hymenomycetes from North America, Mycologia Memoir, 15th Ed., J. Cramer, Stuttgart, Berlin.

Njouonkou, A. L., Mossebo, D. C. (2012). Etude du genre Pleurotus (Fr.) Kummer du Cameroun : Morphologie, caractères culturaux et enzymes extracellulaires, Cameroon Journal of Biological and Biotechnological Sciences, $20: 10-20$. French.

Nobles, M. K. (1958). A rapid test for extracellular oxidase in cultures of wood-inhabiting Hymenomycetes, Canadian Journal of Botany, 36: 91-99.

Oba, R., Tsigaing, T. F., Ngouné Djouké, P., Guifo, C., Fomena, T. M. C., Mossebo, D. C., et al. (2020). Aphyllophorales of Africa 35, New species of Antrodiella and Ceriporiopsis from Cameroon, Synopsis Fungorum, 40: 96-100.

Pegler, D. N. (1977). A preliminary Agaric Flora of East Africa, Kew Bulletin, Additional Series 6, London, HMSO, 615.

Pegler, D. N. (1983). The genus Lentinus, A World Monograph, Kew Bulletin Additional Series 10, London, HMSO, 281.

Ryvarden, L., \& Johansen I. (1980). A Preliminary Polypore Flora of East Africa, Fungiflora, 636.

Ryvarden, L. (1991). Genera of Polypores. Nomenclature and Taxonomy. Synopsis Fungorum, 5: 1-363.

Ryvarden, L., \& Melo, I. (2014). Poroid Fungi of Europe, Synopsis Fungorum, Fungiflora, Oslo, Norway, 31: 455.

Stalpers, J. (1978). Identification of wood inhabiting Aphyllophorales in pure culture, Studies in Mycology, 16: 1-248.

Sullivan, G., \& Henry, E. D. (1971). Occurence and distribution of phenoxazinone pigments in the genus Pycnoporus, Journal of Pharmaceutical Sciences, 60: 1097.

Tichy, V., Klabanova, V., Kucerova, J. (1962). Enzymy drevokaznych hub. III. Zhodnoceni dalsich oxydãzovych testu a jejich pouziti ke studiu podminek produkce lakkãzy, Publ. Fac. Sci. Univ. J. E. purkynĕ, Brno, 436: 395-406. Czech.

Tsigaing, T. F., Oba, R., Metsebing, B. P., Mossebo, D. C., Fomena, T. M. C., et al. (2019). Studies in Aphyllophorales of Africa 34- Two new species from Cameroon and the Democratic Republic of Congo, Synopsis Fungorum, 39: 76-79. 